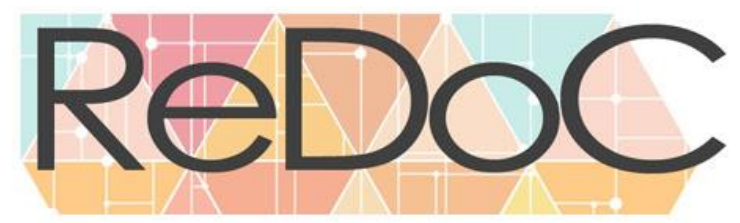

Revista Docência e Cibercultura

\title{
PASSA DEMAQUILANTE NO TEU PRECONCEITO: \\ TUTORIAIS DE MAQUIAGEM COMO PERFORMANCE QUEER NO YOUTUBE
}

\author{
PUT ON MAKEUP REMOVAL ON YOUR PREJUDICE: \\ MAKEUP TUTORIAL AS PERFORMANCE QUEER ON YOUTUBE
}

PASA DEMAQUILLANTE EN TU PRECONCEITO:

TUTORIALES DE MAQUILLAJE COMO PERFORMANCE QUEER EN EL YOUTUBE

\section{RESUMO}

O YouTube é, atualmente, um espaço privilegiado de trocas e de interações no ambiente virtual, no qual reconhecemos uma crescente visibilidade e sucesso de performances que apresentam estéticas e/ou sensibilidades Queer, as quais, de maneira geral, transcendem o limite de um nicho de público LGBTTTQIA ${ }^{3}$ e, cada vez mais, são assistidas por um público heterogêneo. Neste artigo propomos uma leitura do "\#TUTORIAL | Olho tudo + Boca tudo | Esfumado preto com glitter", do famoso maquiador youtuber/influencer Antonio Campagna, enquanto performance Queer que subverter o discurso heteronormativo, que associa a maquiagem ao feminino e à mulher, e possibilita uma fruição lúdica da indeterminação que o Queer promove e celebra.

PALAVRAS-CHAVE: YouTube. Queer. Tutoriais de maquiagem.

\section{ABSTRACT}

The YouTube is, nowadays, a privileged space to exchanges and interactions on virtual environment, which we recognize as an increasing visibility of successful performances that show Queer aesthetics and/or sensitivity, which ones, in general, transcend the limits of the LGBTTTQIA public and, more and more, are watched by a

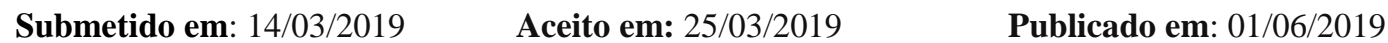

${ }^{1}$ Mestra em Literatura Comparada pela Universidade Regional Integrada do Alto Uruguai e das Missões - URI/ Frederico Westphalen. E-mail: elisangelabertolotti@gmail.com

2 Doutora em Literatura Comparada pela Universidade Federal do Rio Grande do Sul, professora visitante do Mestrado em Artes Visuais da Universidade Federal de Pelotas - UFPel. e-mail:rosangelafachel@ gmail.com

${ }^{3}$ A sigla originalmente criada como LGBT - Lesbicas, Gays, Bissexuais e Trans, e em uso desde 1990, com o passar do tempo e a maior atenção a esses indivíduos e as suas questões, foi sofrendo adequações, sendo essa sua versão mais recente, que identifica: Lésbicas, Gays, Bissexuais, Travestis, Transexuais, Transgêneros, Queer, Intersexo e Assexual. 


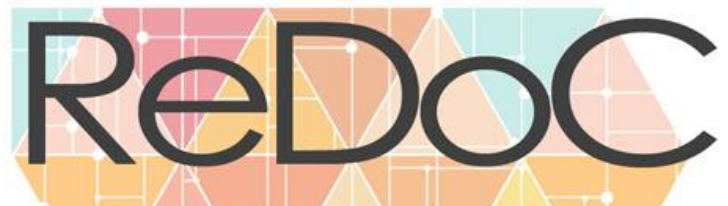

Revista Docência e Cibercultura

heterogeneous public. In this paper we propose an analysis of the "\#TUTORIAL | Olho tudo + Boca tudo | Esfumando preto com glitter", by the famous makeup artist, youtuber/influencer, Antonio Campagna, as a Queer performance which subverts the heteronormative discourse, and associate makeup to the feminine and to woman, and allow a ludic fruition of the indetermination promoted and performed by the Queer.

KEYWORDS: YouTube. Queer. Makeup tutorial.

\section{RESUMEN}

YouTube es actualmente un espacio privilegiado de intercambios y de interacciones en el ambiente virtual, en el cual reconocemos una creciente visibilidad y éxito de performances que presentan estéticas y/o sensibilidades Queer, las cuales, de manera general, trascienden el límite de un nicho de público LGBTTTQIA y, cada vez más, son asistidas por un público heterogéneo. En este artículo proponemos una lectura del "\#TUTORIAL | Ojo todo + Boca todo | "Ahumado negro con glitter", del famoso maquillador youtuber/influencer Antonio Campagna, como performance Queer que subvierte el discurso heteronormativo, que asocia el maquillaje al femenino y a la mujer, y posibilita una fruición lúdica de la indeterminación que el Queer promueve y celebra.

PALABRAS CLAVE: YouTube. Queer. Tutoriales de maquillaje.

A gente tem que lutar sim, todos os dias, passar nosso blush, nosso glitter e sair na rua. E não ter vergonha do que a gente é.

Pabllo Vittar

\section{INTRODUÇÃO}

A expansão e popularização das tecnológicas de comunicação em rede transformou a vida das pessoas, que passam a estar constantemente conectadas - computadores, tablets, smartTVs, mas, sobretudo, são os celulares que mediam as relações interpessoais, os processos de aprendizados e a própria experiência de mundo. O ambiente virtual é hoje o território privilegiado e norteador de trocas e de interações: simbólicas, culturais, sociais, educativas e afetivas, que se intensificaram a partir da Web 2.0, quando o consumidor passou a ser também produtor do conteúdo - prossumidor. Essa perspectiva se acentuou no YouTube, prossumidores se transformam em youtubers, produzindo e difundindo vídeos que respondem a seus interesses e que acreditam que podem interessar a outras pessoas. Muito do conteúdo, atualmente, produzido e difundido na plataforma, pode ser entendido como first person media (mídia em primeira pessoa), sendo o youtuber o Autor/Narrador/Protagonista dos vídeos que publica. Quando um youtuber alcança muito sucesso, engajando legiões de seguidores, ele se torna um influencer (influenciador) - não apenas em relação às temáticas 


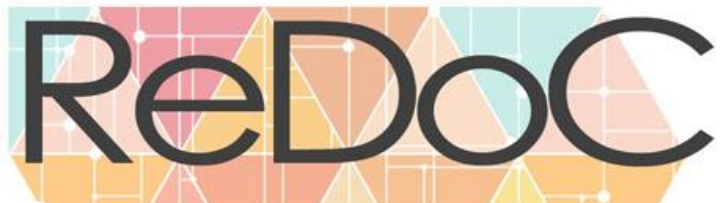

Revista Docência e Cibercultura

que aborda, mas, também, quanto à maneira como o faz, à maneira como se expressa, e à forma como é reconhecido e identificado por seus seguidores.

A facilidade para a produção e divulgação de conteúdos, bem como a ideia (nem sempre verdadeira) de segurança para a autoexposição, transformaram a internet e, de maneira especial, o YouTube, em território percebido como seguro para a livre expressão, tanto por youtubers quanto por viewers (espectadores no contexto da internet). Muitos sujeitos LGBTTTQIA têm utilizado a plataforma seja como espaço para o discurso engajado e político de autoafirmação identitária, seja como espaço em que se permitem exibirem-se sem censura ou temor, em ambos os casos enfrentam e rompem padrões socioculturais, ideológicos, políticos e estéticos heteronormativos. E mesmo que, muitas vezes, sejam vítimas do ataque de haters $^{4}$, reconhecemos uma crescente visibilidade e sucesso de performances $^{5}$ masculinas que apresentam estética e/ou sensibilidade Queer, as quais, de maneira geral, transcendem o limite de um nicho de público LGBTTTQIA e, cada vez mais, são assistidas por um público heterogêneo.

O sucesso dos tutoriais de maquiagem e, dentre esses, o sucesso dos que são produzidos por jovens do sexo masculino, que se automaquiam como forma de ensinar maquiagem, mas também de se expressar, instigou-nos a pensa-los no jogo que estabelecem entre a temática da maquiagem e as questões contemporâneas de gênero e de identidade. Queremos entender se os tutoriais de maquiagem produzidos por youtubers/influencers masculinos, rompendo assim com padrões socioculturais heteronormativos, podem contribuir para a visibilidade, autoafirmação e representatividade Queer. Para tanto, analisamos um dos mais visualizados tutoriais de maquiagem do famoso maquiador youtuber/influencer Antonio Campagna, intitulado “\#TUTORIAL | Olho tudo + Boca tudo | Esfumado preto com glitter”.

\footnotetext{
${ }^{4}$ Palavra inglesa, que se poderia traduzir como "odiadores", utilizada para designar indivíduos que disseminam discursos de ódios e/ou atacam discursivamente pessoas em redes sociais e plataformas de interação virtual.

${ }^{5}$ Referimos a ideia de performance em sua acepção no campo das artes, como definida Richard Schechner: "As performances marcam identidades, modificam e redimensionam o tempo, enfeitam e remodelam o corpo, contam histórias, permite que se jogue com condutas repetidas, que sejam preparadas e ensaiadas, apresentadas e representadas tais condutas" $(2000$, p.13).
}

\begin{tabular}{l|l|l|l|l|l|l} 
(C) Redoc & Rio de Janeiro & v. 3 & n.1 & p.153 & Jan/Abr. 2019 & e-ISSN 2594-9004 \\
\hline
\end{tabular}




\section{A ERA DOS YOUTUBERS}

Criado em 2005, por Chad Hurley, Steve Chen e Jawed Karim, e adquirido pela Google em 2006, o YouTube é, atualmente, a segunda rede social mais visitada do mundo ${ }^{6}$. O nome da plataforma deriva da união das palavras inglesas: you (você) e tube ("tubo" ou “canal”, e, também, uma gíria para designar "televisão"). Poderíamos entender a palavra YouTube, então, como "você transmite" ou "canal feito por você", o que sintetiza muito bem a proposta da plataforma, criada para o compartilhamento de conteúdos audiovisuais: préexistentes, como trechos de filmes e de programas de televisão, obras audiovisuais completas, videoclipes; ou produzidos pelos internautas, como edição de materiais audiovisuais préexistentes, videoblogs, vlogs e tutoriais.

A utilização do canal para a promoção pessoal foi ganhando cada vez mais espaço e resultou na mudança no slogan da plataforma de Your Digital Video Repository (seu repositório de vídeos digitais) para Broadcast Yourself (transmita-se), que instiga os indivíduos a serem produtores e transmissores de si. Essa mudança respondeu à própria transformação no comportamento dos usuários da internet, que desvelavam as possibilidades da rede como um ambiente de interação e de participação, que envolvia wikis $^{7}$, aplicativos baseados na folksonomia ${ }^{8}$, redes sociais, blogs e todo o tipo de tecnologias da informação e da comunicação em rede. Essa nova configuração de interação na internet foi reconhecida como a segunda geração da Web, a Web 2.0 (termo cunhado pela empresa O'Reilly Media), que passava a ser entendida a partir de então como uma plataforma. Rapidamente os usuários começaram a explorar o amplo potencial de difusão de conteúdo no YouTube.

Para compartilhar vídeos é preciso que o usuário crie seu próprio canal, o qual está associado a uma conta/perfil do Google, sendo o usuário responsável por definir se o conteúdo será disponibilizado de forma pública ou privada. No entanto, como salienta Henry Jenkins, apesar de ser o epicentro da "cultura participativa", o YouTube "não representa o

\footnotetext{
${ }^{6}$ Em junho de 2017, o Youtube divulgou durante a VidCon, realizada na Califórnia - EUA, que alcançava o número de 1,5 bilhão de acessos por mês.

7 Termo utilizado para identificar uma coleção de documentos em hipertexto, ou o software colaborativo utilizado para cria-los.

${ }^{8}$ Classificação social e colaborativa de conteúdo na internet por meio da utilização de tags.
}

\begin{tabular}{l|l|l|l|l|l|l} 
(C) Redoc & Rio de Janeiro & v. 3 & n.1 & p. 154 & Jan/Abr. 2019 & e-ISSN 2594-9004
\end{tabular}




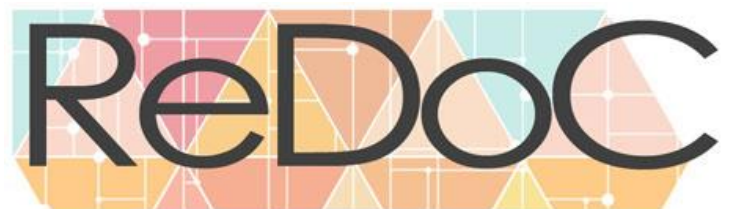

Revista Docência e Cibercultura

ponto de origem para qualquer das práticas culturais associadas a ele" (JENKINS, 2009, p. 145). Conforme dados recentes levantados pelo Projeto Alfabetismo Transmedia: un programa de investigación, ${ }^{9}$ do Programa Horizonte 2020 da União Europeia, liderado por Carlos Scolari, e publicados no Libro Blanco - Alfabetismo Transmedia en las nuevas Ecología de los Medios (2018); a "produção de conteúdos" é a principal e mais destacada competência de atuação dos jovens no contexto contemporâneo de ecologia das mídias.

O YouTube transformou-se, assim, em espaço privilegiado da "mídia em primeira pessoa" - produção centrada no discurso direto e em primeira pessoa do "autor", do "eu". Em O Show do eu (2008), Sibilia, discorre sobre as diferentes dimensões do "eu" na internet e a maneira como as dimensões íntimas e confessionais do âmbito da vida privada são rearticuladas para uma exposição pública, que tem por objetivo legitimar formas de ser e de estar no mundo. Tais "escritas de si" ou "narrativas do eu", são produzidas por um “Autor/Narrador/Protagonista" (SIBILIA, 2008) - que surge em um contexto midiático de conexão e interação ubíqua e onipresente. Conforme Sibilia, a vida do autor/narrador/protagonista só passa a existir quando é "relatada em primeira pessoa do singular" (SIBILIA, 2008, p. 33). Nesse sentido, não há surpresa em que essas produções girem em torno do eu, sendo discursos de testemunhos, confissões, lembranças e/ou performance de autoexibição (MENEGON, 2013, p. 28). Por terem essa configuração autocentrada tais produções foram denominadas por Bruno Costa (2009) de "videografias do si”. No entanto, as possibilidades de interação oferecidas pelas plataformas, transformaram esse autor/narrador/protagonista em um narrador interativo.

A conjunção de elementos audiovisuais estéticos e narrativos recorrentes na configuração dos vídeos divulgados nos canais do YouTube foi aos poucos constituindo o que hoje reconhecemos como linguagens específicas do meio, e no caso específico das produções realizadas por Autor/Narrador/Protagonista, o formato predominante é o do vlog:

O vlog (abreviação para 'videolog') é uma forma predominante do vídeo "amador" no YouTube, tipicamente estruturada sobre o conceito do monologo feito

\footnotetext{
${ }^{9}$ Conforme Scolari (2018), o Projeto Alfabetismo Transmedia não se limita à análise de práticas participativas, à geração de conteúdo pelos jovens ou às estratégias informais de aprendizagem: vai mais longe da pesquisa científica e propõe alternativas para beneficiar-se das competências trasmídia, desenvolvidas pelos adolescentes fora das escolas por meio de sua aplicação dentro do sistema educativo formal.
} 
diretamente para a câmera, cujos vídeos são caracteristicamente produzidos com pouco mais que uma webcam e pouca habilidade em edição. Os assuntos abordados vão de debates políticos racionais a arroubos exacerbados sobre o próprio YouTube e detalhes triviais da vida cotidiana. (MONTANHA, 2011, p. 192)

Outra fórmula utilizada no YouTube e identificada como muito apreciada pelos viewers, são as Lives - transmissões ao vivo, que reforçam a ideia de intimidade entre produtor e receptores.

Michael Wesch, um dos primeiros a estudar o fenômeno do YouTube, claramente na esteira de Marshall McLuhan, chama a atenção para o fato de que uma "nova mídia não apenas introduz uma nova forma de nos expressarmos, mas também novas formas de autoconsciência - novas maneiras de refletir sobre quem nós somos e como nos relacionamos com os outros" (WESCH, 2009, p. 19 - tradução das autoras). ${ }^{10}$ Wesch (2009) argumenta que a webcam com seu potencial de conexão global conecta espaços privados criando um contexto perfeito para o compartilhamento de momentos profundos de autorreflexão e, assim, gerando conexões que são intensamente experimentadas, mas que permanecem efêmeras e soltas. Já em seus primeiros trabalhos, Wesch batiza esse Autor/Narrador/Protagonista das narrativas audiovisuais do YouTube de youtuber.

Conforme Camilo Coutinho, a decisão por assistir um vídeo é $60 \%$ motivada pelas thumbnails (imagem estática em miniatura, como se fosse uma capa, que apresenta o vídeo) e 40\%, resultado dos vídeos. Além disso, Coutinho destaca a importância dos "conteúdos periféricos" gerados a partir dos vídeos como GIFs e memes na divulgação e no sucesso dos vídeos e canais. O principal elemento para a consolidação de um canal do YouTube - seja informativo, que produzem vídeos (como, por exemplo, tutoriais), sobre uma determinada temática específica: maquiagem, culinária, games, cinema, literatura, computação, etc.; ou narrativo - ficcionais, documentais ou de depoimento/testemunho: webséries e vlogs; é a identificação com um público-alvo. Instaurada a relação de confiança e credibilidade entre o youtuber e seu público, muito dos vídeos divulgados serão respostas a demandas, tentando atender às solicitações do público. Sendo assim, os vídeos têm uma edição dinâmica que busca otimizar o tempo - acelerando e/ou fragmentando sequencias. Além disso, os youtubers

\footnotetext{
${ }^{10}$ New media not only introduce new ways for us to express ourselves, but also new forms of self-awarenessnew ways to reflect on who we are and how we relate to others.
} 


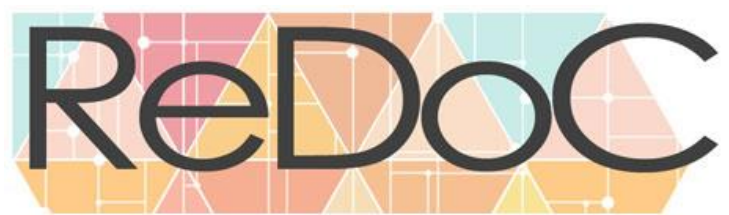

\section{Revista Docência e Cibercultura}

se comunicam por meio de uma linguagem que é compartilhada por seu nicho, assim, gamers (youtubers de games - videojogos) e vloggers de maquiagem, utilizam palavras e expressões que são pertinentes a seus campos específicos de interesses e que, assim, estabelecem um universo significativo compartilhado e de autoidentificação.

Os youtubers produzem vídeos sobre as mais variadas temáticas e áreas ${ }^{11}$, atendendo tal diversidade de conteúdos aos mais variados e segmentados públicos assim como a todas as faixas-etárias - crianças, jovens e adultos. A temática abordada pelo canal associada ao tipo de conteúdo e à performance do youtuber formam a equação que resulta, ou não, no sucesso de visualizações do Canal. A fama de alguns youtubers - que se tornam então influencers, pode ser explicada, portanto, pela forma como saem do modo tradicional de comunicação para abordar assuntos que interessam a públicos específicos (SANTAELLA, 2007). Por meio dessa relação que nasce da adesão à temática explorada pelo youtuber em seu canal se inicia uma relação de admiração, empatia, credibilidade e confiança do viewer em relação ao vlogger e, muitas vezes, de identificação com aquilo que ele representa, que é alimentada por o que John Thompson (2008) identificou com uma "intimidade não-recíproca à distância", uma intimidade mediada (pelos meios/mídias) que se configura na interface da tela (do computador/smartphone).

Considerando que a quase-interação mediada é, tipicamente, altamente monológica e que envolve a produção de formas simbólicas direcionadas a um espectro indefinido de receptores em potencial, pode ser vista como um tipo de quaseinteração. Ela não tem o mesmo nível de reciprocidade e de especificidade interpessoal de outras formas de interação, seja mediada ou face-a-face. Mas a quase-interação mediada é, de qualquer modo, uma forma de interação. Ela cria também diversos tipos de relacionamentos interpessoais, vínculos sociais e intimidade (o que chamo de «intimidade não-recíproca à distância») (THOMPSON, 2008, p. 19)

Essas celebridades da internet advêm de diversas áreas e interesses, e a disseminação e o sucesso de seus vídeos contribuem para que alcancem prestígio junto a seu público e, assim, ascendam à condição de influência (influencer) na construção e afirmação identitária. Suas

\footnotetext{
11 A plataforma mantém políticas de controle de conteúdo referentes à preservação dos direitos autorais e à exibição de imagens de nudez e de conteúdo sexual, bem como restrição de idade para alguns conteúdos.
} 


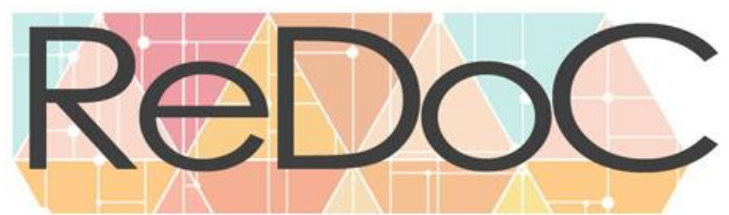

Revista Docência e Cibercultura

narrativas alcançam distintos públicos e fornecem informações, soluções e identificação. Esse poder de identificação e de afirmação identitária que advém do sucesso de visualizações e de engajamento dos viewers (comentários, likes e, principalmente, compartilhamentos) vem sendo explorado consciente ou inconscientemente por muitos Canais do YouTube e por seus Autor/Narrador/Protagonista, bem como pela própria plataforma que possui um programa de parceira que permite aos produtores de conteúdo a geração de renda por meio da apresentação de anúncios - no âmbito mercadológico reconhecer e estabelecer a identificação dos viewers com o conteúdo e com o canal é extremamente importante. ${ }^{12}$

A interação dos viewers - por meio de comentários e likes, é fundamental para o engajamento e fidelização, que os transformam em seguidores, e é essencial para o sucesso do canal. Essa possibilidade de interconexão virtual e em rede permite aos indivíduos manifestarem opiniões e discursos referentes a seus interesses, e promove sua aproximação e interação com outros indivíduos que manifestam interesses, necessidades e expectativas semelhantes. Nesse sentido, os canais do YouTube se revelam locais de confluência e de identificação dos viewers tanto em relação ao influencer quanto entre si. É possível inferirmos, então, a importância que youtubers-influencer podem ter na construção e afirmação identitára de seus seguidores-viewers.

\section{REPRESENTATIVIDADE $Q U E E R$ NO YOUTUBE}

A liberdade de expressão possibilitada pelo YouTube, bem como a sensação de segurança dos vlogers ao gravarem seus vídeos dentro da própria casa ou em algum ambiente controlado, têm transformado a plataforma em espaço perfeito para a manifestação de opiniões e de posicionamentos: ideológicos, culturais, sociais e políticos - muitas vezes, fazendo referência a questões identitárias de gênero e de raça. Assim, as plataformas virtuais são utilizadas, também, para promover a visibilidade e a discussão de conteúdos que, de maneira geral, não possuem

\footnotetext{
12 Philip Kotler (2017), chama a atenção para o poder mercadológico dos influencers (youtubers, blogueiros, vlogueiros), cuja capacidade de comunicação, por meio de uma abordagem particular de assuntos variados, atrai, fideliza e cria confiança em seus viewers. Esse poder já é reconhecido por muitas empresas que pagam para associar suas marcas e produtos a influencers que atuem junto a seus nichos de mercado, já que as mensagens transmitidas por essas personalidades causam mais impacto e confiança no ato da compra. Ou seja, o público adere com mais facilidade as opiniões expostas pelos influencers do que a outro tipo de comercial ou divulgação.
} 


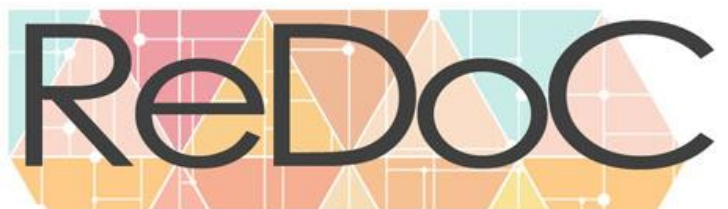

Revista Docência e Cibercultura

espaço nas mídias institucionalizadas. Em paralelo aos movimentos afirmativos que conclamam à busca por igualdade e ao enfrentamento de preconceitos e estereótipos, o YouTube fornece espaço para as manifestação da diversidade - diferentes identidades, faixas etárias, formas físicas e corpos, que expressam diferentes pensamentos, sexualidades, gêneros etc. Tais canais e performances, fomentam novos discursos e debates, sendo um ponto de escape virtual no qual é permitido questionar(-se) e romper padrões socioculturais.

O YouTube oportuniza que as vivências subjetivas dos sujeitos sejam exibidas. E diferentes práticas e vivências socioculturais e identitárias sejam expostas, configurando-se como um espaço importante para a manifestação e representatividade Queer, principalmente, no que diz respeito à sua visibilidade. Para compreendermos a importância dessa representatividade, lembramos que a ressignificação do termo Queer aconteceu nos anos oitenta, quando "militantes e pesquisadores da causa gay, principalmente nos Estados Unidos", buscaram "ressignificar o termo, retirando-o do sentido pejorativo com a proposta de positivá-lo, tendo como proposta central o rompimento com o binarismo" (COSTA; SILVA JUNIOR, 2014, p. 4). E, desde então, muito teóricos retomam, com a intenção de discutir e reconfigurar o que é ser Queer. Para Guacira Lopes Louro, o Queer é

[...] o excêntrico que não deseja ser "integrado" e muito menos "tolerado". Queer é um jeito de pensar e de ser que não aspira o centro nem o quer como referência; um jeito de pensar e de ser que desafia as normas regulatórias da sociedade, que assume o desconforto da ambiguidade, do "entre-lugares", do indecidível. Queer é um corpo estranho, que incomoda, perturba, provoca e fascina (LOURO, 2013, p.08)

Essa fluidez identitária híbrida e movediça, que o Queer representa, pode ser entendida como um contraponto à performatividade de gênero, identificada por Judith Butler (2008), que é responsável pela produção dos sujeitos como resultado de recorrentes repetições na maioria das vezes ritualística que excluem e estigmatizam aqueles que saem das regras estabelecidas. Ao desvelar esse processo performativo, Butler (2008) propõe que deixemos de pensar as categorias "homem" e "mulher" como fixas e passemos a entendê-las como formas de representação dos sujeitos, promovendo assim a reflexão acerca da produção de subjetividade como resultado da convivência social e do que ela pressupõe como correta. A subversão dessa ordem sociocultural abre espaço para outras formas de ser e estar, que dão 


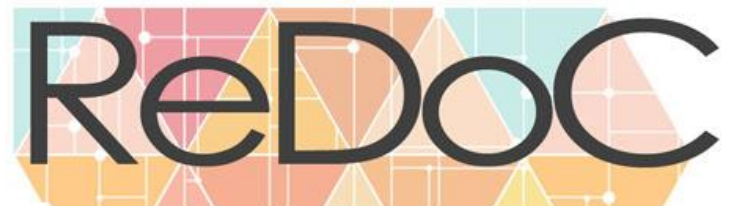

Revista Docência e Cibercultura

vazão ao amplo espectro do humano em contraposição à ideia de singularidade e ao essencialismo, que se alicerçam na ideia de uma convergência intrínseca entre sexo e gênero.

A noção binária de masculino/feminino constitui não só a estrutura exclusiva em que essa especificidade pode ser reconhecida, mas de todo modo a 'especificidade' do feminino é mais uma vez totalmente descontextualizada, analítica e politicamente separada da constituição de classe, raça, etnia e outros eixos de relações de poder, os quais tanto constituem a 'identidade' como tornam equívoca a noção singular de identidade (BUTLER, 2008, p. 21).

Na esfera discursiva audiovisual do YouTube, o Queer se manifesta de maneira mais evidente por meio da sensibilidade Camp. Para Susan Sontag (1964 - tradução das autoras) ${ }^{13}$, essa sensibilidade camp está em "seu amor pelo afetamento: pelo artifício e pelo exagero" e tem na androgenia uma de suas imagens eminentes. Para Denilson Lopes (2002, p. 95), a sensibilidade camp está associada à "atitude exagerada de certos homossexuais, ou simplesmente à afetação”. E, conforme Lauro Maia Amorim (2015, p. 167-168), no âmbito da linguagem,

[...] o camp seria um fenômeno sociolinguístico que se efetiva entre falantes homossexuais masculinos no seio de uma comunidade na qual seus membros assumem e performam a identidade gay por meio de signos e estratégias linguísticopragmáticas que se valem, inclusive, de estereótipos com o objetivo de demarcar uma identidade sexual distinta. Há vários aspectos que caracterizam o camp, dentre os quais se destacam a ironia à renomeação dos próprios sujeitos homossexuais por meio de apelidos sugestivos, em geral relacionados à feminilidade. [...] $\mathrm{O}$ estilo Camp também se vale da imitação teatralizada da linguagem feminina (girl-talk) e por exclamações que acentuam o efeito de teatralização.

Enquanto espaço virtual "livre", o YouTube tem extrema relevância para a visibilidade de sujeitos LGBTTQIA e de performances que rompem com o padrão heteronormativo, geralmente, estigmatizados. É nesse espaço virtual que, finalmente, muitos desses sujeitos conseguem expressar suas identidades e estabelecer relações individuais e de comunidades. Vozes e imagens, comumente, reprimidas pela sociedade ganham espaço e se multiplicam por meio de canais, vídeos etc.

\footnotetext{
${ }^{13}$ Indeed the essence of Camp is its love of the unnatural: of artifice and exaggeration.
}

\begin{tabular}{|l|l|l|l|l|l|r|} 
(C) Redoc & Rio de Janeiro & v. 3 & n.1 & p. 160 & Jan/Abr. 2019 & e-ISSN 2594-9004
\end{tabular}




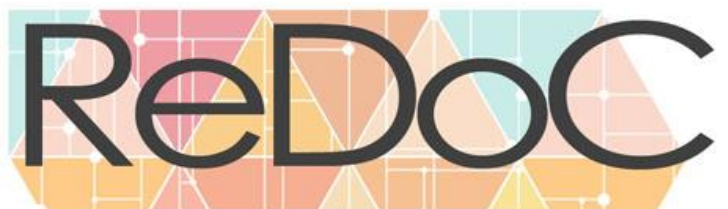

Revista Docência e Cibercultura

No entanto, não podemos ser ingênuos ao ponto de pensarmos que o YouTube é um paraíso para a livre expressão democrática de todas as identidades. Em 2017, a plataforma teve de esclarecer que iria rever os critérios da ferramenta de restrição de vídeos ${ }^{14}$, após a acusação da dupla canadense Tenga e Sara (declaradamente homossexuais), de que a ferramenta estaria ocultando seus vídeos, reconhecendo-os como "potencialmente inapropriados" - apesar de não apresentarem imagens violentas ou sexuais. Para as jovens cantoras, o modo restrito, ativado pela ferramenta de restrição, estaria censurando conteúdos LGBTTTQIA. Na mesma época, a vlogueira Rowan Ellis, ativista LGBTTTQIA, declarou em um vídeo intitulado "O YouTube é anti-LGBTQ?", que quarenta de seus vídeos haviam sido bloqueados simplesmente por abordarem questões relacionadas às identidades LGBTTTQIAs. Para Ellis limitar o acesso de jovens LGBTTTQIA a esses conteúdos é um crime, pois o YouTube seria um dos únicos espaços em que esses jovens encontrariam apoio e conselhos. E, a partir dessa percepção, ela questionou o motivo oculto para esses vídeos haverem sidos bloqueados (ELLIS, 2017).

Em contrapartida, lembramos o exemplo brasileiro da cantora, compositora e Drag Queen Pabllo Vittar, fenômeno midiático, alçado à fama pelo videoclipe Open bar (2015), que fez grande sucesso no YouTube. Os vídeos de Pabllo Vittar dão visibilidade à sua performance híbrida e fluida, liberta da heteronormatividade vigente, rompendo preconceitos e barreiras socioculturais ainda vigentes e fortes. E foi essa exposição em seu canal do YouTube, disponibilizando videoclipes e $\log s$, que impulsionou sua carreira e a levou a tornar-se uma das mais importantes influencers contemporâneas brasileiras. Assim, apesar de não ser um espaço completamente livre e independente de preconceitos e censuras, alicerçadas em uma heteronormatividade estrutural, reconhecemos o potencial do YouTube como espaço de produção e intervenções socioculturais e identitárias, que permite a dinamização e a construção de discursos de representatividade e de questionamentos de representações.

Cabe ressaltar que a autoexposição de sujeitos Queer e/ou a produção e divulgação de conteúdos e repertórios Queer em vídeos no YouTube nem sempre são manifestações políticoidentitárias engajadas de autoafirmação. No entanto, é inegável que essas produções promovem a

14 Conforme definição do YouTube, o recurso de restrição de vídeos permite aos usuários filtrarem conteúdos que não são apropriados para menores de 18 anos, sendo uma ferramenta "opcional para ajudar instituições como escolas, bem como usuários que querem controlar melhor o conteúdo que veem”. 


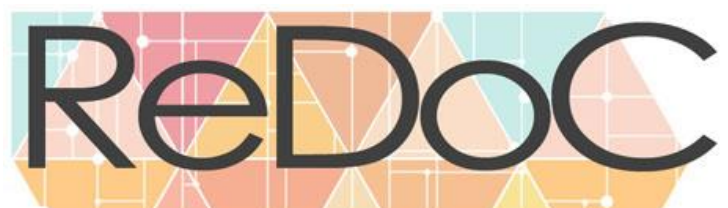

\section{Revista Docência e Cibercultura}

visibilidade de tais representações e, quem sabe, até de maneira mais efetiva. Um ponto forte é a naturalidade do discurso coloquial e espontâneo, inerente à linguagem do YouTube, no qual emerge uma linguagem camp que não apenas está liberta das censuras heteronormativas como utiliza isso a seu favor - seja como elemento de identificação com aqueles que compartilham dos mesmos códigos linguísticos, seja como uma brincadeira com aqueles que esperam essas diferenças.

Dentre as muitas produções referentes ao espectro Queer difundidas no YouTube, entendemos que os tutoriais de maquiagem realizados por jovens maquiadores youtubers, ao romperem com padrões e categorias heteronormativas e negarem estratificações estanques entre o que é do universo masculino e o que é do universo feminino, se configuram como um poderoso discurso Queer, mesmo essa não seja uma intenção consciente. Sob essa perspectiva, analisamos um dos mais visualizados tutoriais de maquiagem do famoso youtuber maquiador - Antonio Campagna.

\section{DO IT YOURSELF - FAÇA VOCÊ MESMO: OS TUTORIAIS DO YOUTUBE}

Os tutoriais audiovisuais criados e divulgados no YouTube atendem as mais variadas demandas nos mais diversos campos - computação, culinária, moda, maquiagem, saúde, entre muitos outros, tendo por objetivo a solução de um problema ou o esclarecimento de uma dúvida. E atravessam a interface de maneira ativa, uma vez que o produtor/autor desses vídeos tem por objetivo ensinar "como fazer" algo ao receptor/viewer por meio da apresentação de um "passo a passo". Para nós o sucesso dos tutoriais pode ser relacionado a perspectivas de ensino/aprendizagem que imbricam ações reconhecidas pelo Projeto Alfabetismo Transmedia: un programa de investigación como "estratégias informais de aprendizagem" utilizadas pelos jovens na contemporaneidade: prática; resolução de problemas; imitação; jogo; avaliação; e ensino. Conforme resultados levantados pelo Projeto, apresentados no relatório Libro Blanco: "YouTube es uno de los espacios de aprendizaje en línea más importantes, y ocupa un lugar central en el consumo mediático de contenidos y (a veces) incluso en su producción \#TransmediaLiteracy" (SCOLARI, 2018). 
No universo dos tutoriais é perceptível o destaque dos tutoriais de maquiagem, corroborado pelo simples teste de começarmos a digitar no buscador do Google: "tutorial para", a o que logo nos é sugerida a busca por conteúdos relacionados ao campo da maquiagem e da beleza:

Figura 1: Pesquisa no Google.

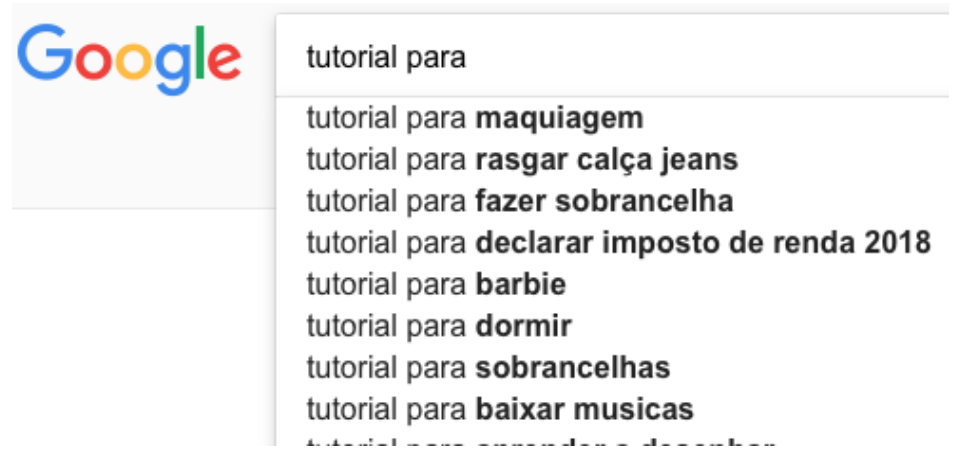

Fonte: Captura de tela

A proeminência desses conteúdos relacionados à palavra tutorial revela a frequência da procura por essa combinação de palavras: tutorial + maquiagem; tutorial + make, o que é um sinal do grande interesse das pessoas por tais conteúdos. O mesmo teste realizado na página do YouTube revela uma situação ainda mais proeminente, reafirmando, então, que os tutoriais mais buscados e visualizados são os de maquiagem.

Figura 2: Pesquisa no YouTube.

\begin{tabular}{|c|c|c|}
\hline$\equiv$ & - YouTube ${ }^{\mathrm{BR}}$ & tutorial de| \\
\hline & Início & tutorial de maquiagem \\
\hline 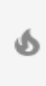 & Em alta & $\begin{array}{l}\text { tutorial de maquiagem para iniciantes } \\
\text { tutorial de unhas }\end{array}$ \\
\hline 言 & Inscrições & tutorial de maquiagem simples \\
\hline \multicolumn{2}{|c|}{ BIBLIOTECA } & $\begin{array}{l}\text { tutorial de batom } \\
\text { tutorial de make }\end{array}$ \\
\hline (1) & Histórico & tutorial de sobrancelha \\
\hline (2) & Assistir mais tarde & tutorial de cabelo \\
\hline ite & Vídeos marcado... & $\begin{array}{l}\text { tutorial de como beber agua } \\
\text { tutorial de desenho }\end{array}$ \\
\hline$\equiv$ & Cine Argentino. P... & \\
\hline
\end{tabular}

Fonte: Captura de tela.

\begin{tabular}{l|l|l|l|l|l|r} 
(C) Redoc & Rio de Janeiro & v. 3 & n.1 & p. 163 & Jan/Abr. 2019 & e-ISSN 2594-9004 \\
\hline
\end{tabular}




\section{TUTORIAIS DE MAQUIAGEM COMO PERFORMANCE QUEER}

Os tutoriais de maquiagem, cada vez mais, são incrementados por seus realizadores, que buscam uma maior repercussão, ao se utilizarem de estratégias para chamar a atenção do públicoalvo: criação de thumbnail instigantes - que geralmente apresentam imagens dos rostos maquiados dos youtubers (muitos apresentam a estrutura visual do "antes e depois"), as quais são sobrepostas de um título direto e chamativo, em letras maiúsculas; descrições objetivas, mas pessoais do conteúdo dos vídeos. Todos esses elementos têm por objetivo levar o internauta a abrir e a assistir aos vídeos. Abertos os vídeos, a forma como os youtubers se comunicam, sua linguagem e a maneira como se dirige a seus viewers, seu gestual, seu estilo - roupas, maquiagem, cabelo - contribuem para o engajamento do público com o autor e com seu Canal. Outra característica recorrente nos canais mais famosos dedicados a tutoriais e dicas de maquiagem é que recebam o nome do(a) youtuber que os criou e administra, que, na perspectiva do "faça você mesmo", se maquia em frente à câmera para assim passar seus conhecimentos a seus espectadores.

O universo da maquiagem reconhecido pelo senso comum heteronormativo como campo das mulheres e do feminino ganha novos contornos no YouTube. Apesar da preponderância de mulheres como produtoras de tutoriais de maquiagem, alguns jovens rapazes vêm se destacando nesse campo. É notório, no entanto, que no Brasil, mesmo antes do advento do YouTube já eram conhecidos alguns famosos maquiadores, que atuavam na área da televisão e da teledramaturgia, maquiando mulheres famosas, socialites e estrelas da televisão; e que, vez por outra, apareciam ensinando truques de maquiagem em programas televisivos. Mas essas maquiagens estavam sempre destinadas ao campo do feminino, aos rostos de mulheres, travestis, transformistas e Drag Queens - e nessas de maneira exagerada e performática. Os jovens maquiadores do YouTube, na "era da cibercultura", ao contrário de seus predecessores que brilhavam na televisão, na "era das mídias" (SANTAELLA, 2003), maquiando mulheres famosas e atrizes, vão para a frente da câmera maquiar a si mesmos para assim ensinar, passo a passo, seus espectadores a se maquiarem. Eles rompem assim com limites heteronormativos em relação ao campo da maquiagem e do corpo: são jovens maquiadores que se maquiam em frente às câmeras para 


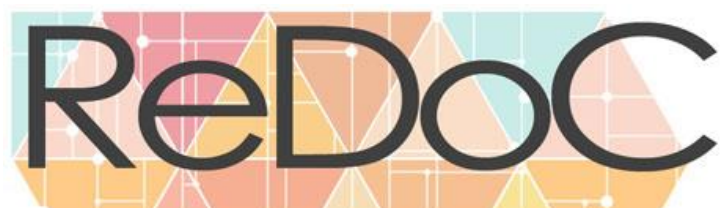

\section{Revista Docência e Cibercultura}

ensinar mulheres a se automaquiarem (mas há também tutoriais destinados a maquiagens masculinas), o travestimento pode acontecer, mas não é recorrente.

Um exemplo internacional dessa tendência de sucesso de tutoriais de maquiagem realizados por jovens do sexo masculino, é Jack, que com apenas 15 anos faz o maior sucesso com seus tutoriais de maquiagem postados em seus perfis no instagram e em seu canal do YouTube, intitulado "makeuupbyjack", que já tem mais de 31.000 inscritos ${ }^{15}$ e apresenta, além de tutoriais, vídeos de Jack falando sobre assuntos solicitados por seus seguidores. O sucesso do canal de Jack, assim como de outros youtubers do campo da maquiagem, vai além da qualidade notória de seus tutoriais, que agradam o público, estando relacionado à imagem dos youtubers e às múltiplas questões subjetivas associadas a suas produções e à maneira como acabam constituindo um discurso identitário e de representatividade. A perspectiva de narrativa em primeira pessoa, diretamente destinada ao espectador, aproxima o youtuber do espectador, sendo uma excelente e segura maneira de propor o enfrentamento de preconceitos e de diferenças, que talvez não seria tão tranquilo além da interface.

\section{“\#TUTORIAL | Olho tudo + Boca tudo | Esfumado preto com glitter | Antonio Campagna"}

Conhecido por ser referência em contornos faciais, subterfúgio de maquiagem que cria a ilusão de remodelamento do rosto, muito utilizado, por exemplo, para suavizar os traços masculinos do rosto, Campagna - maquiador/youtuber/influencer, afirma que seus vídeos de mais sucesso (visualizações, comentários e curtidas) são aqueles em que ele aparece se automaquiando. O canal de Campagna tem mais de 24.000 inscritos $^{16}$ e seus vídeos são sucesso de visualização e de repercussão nos comentários. O principal conteúdo do canal são os tutoriais de maquiagem, identificados já no título dos vídeos que sempre começam com: \#TUTORIAL, seguido então pela descrição do que será ensinado. Na maioria das vezes, os tutoriais de Campagna são visualmente muito simples: o youtuber está em um ambiente

\footnotetext{
${ }^{15}$ Dados referentes a fevereiro de 2019.

${ }^{16}$ Dados referentes a fevereiro de 2019.
} 


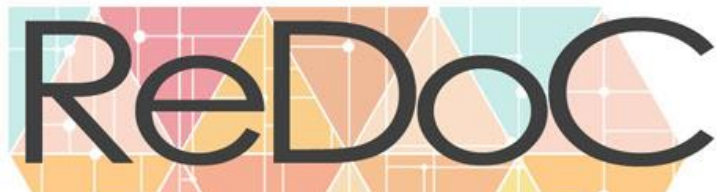

Revista Docência e Cibercultura

simples, comodamente sentado e colocado em frente à câmera, geralmente, usando roupas simples e andrógenas, falando diretamente com seus viewers e maquiando-se.

Em entrevista ${ }^{17}$, Campagna contou que sempre gostou de maquiagem, mas somente após fazer um curso de maquiagem na Europa decidiu expressar a sua autenticidade e sua personalidade por meio da maquiagem. É interessante destacar que ele afirma ter aprendido a maquiar observando outros profissionais e fazendo testes em si mesmo, mas ao começar a mostrar seu trabalho nas redes sócias, ele apresentava apenas maquiagens feitas em clientes e nunca postava fotos do próprio rosto maquiado, "principalmente, por medo" da reação preconceituosa das pessoas. Seus vídeos recebem inúmeros elogios de pessoas que admiram o seu trabalho, geralmente jovens, em sua maioria mulheres, mas com a presença também de homens - dentro da diversidade de seu público é interessante percebermos como o universo LGBTTTQIA é celebrado e reafirmado pelos discursos - que muitas vezes repetem e se apropriam de falas e expressões utilizadas no tutorial. O sucesso, medido pelos wiews e likes de seus vídeos, revela o grau de representatividade do maquiador, que em seu perfil no Instagran, se apresenta como "beauty influencer" (influenciador no campo da beleza). Os comentários em seus vídeos revelam a grande admiração de seus seguidores, que o incentivam à produção de novos vídeos, elogiam as maquiagens que ele realiza, o modo como ele desenvolve o vídeo e a maneira como ele cativa seus seguidos, sua simpatia e sua simplicidade.

\footnotetext{
${ }^{17}$ Para o programa "Deu certo multimídia", realizada pelo canal "Jornalismo UCDB"
} 


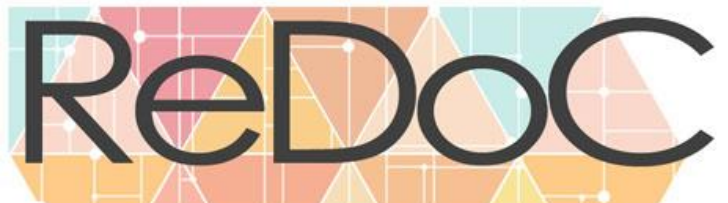

Revista Docência e Cibercultura

Figura 3: Print dos comentários ao \#TUTORIAL | Olho tudo + Boca tudo | Esfumado preto com glitter

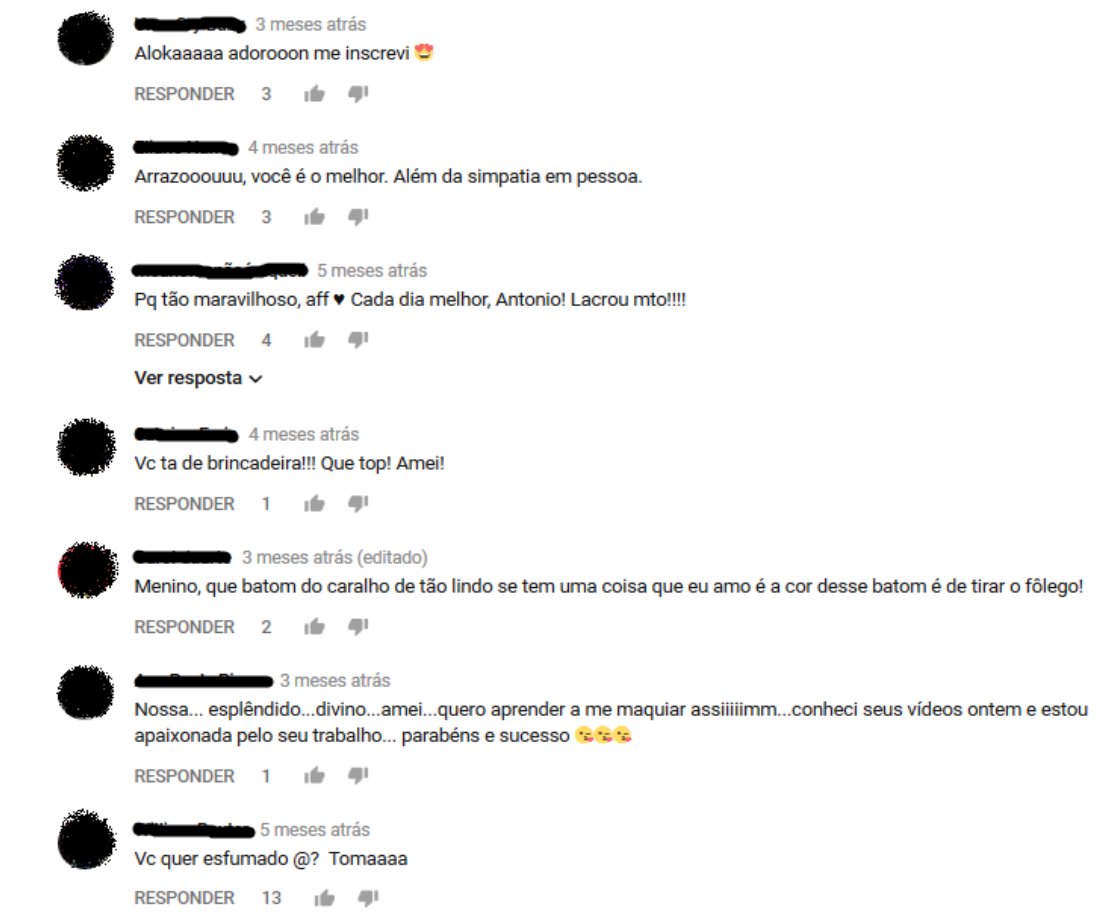

Fonte: Captura de tela - Canal do YouTube. Disponível em:

<https://www.youtube.com/watch?v=h4F1SsLmxGw> Acesso em: 11 abr. 2018.

O tutorial “\#TUTORIAL | Olho tudo + Boca tudo | Esfumado preto com glitter | Antonio Campagna", publicado em 12 de setembro de 2017, foi selecionado como objeto de nossa análise por ser um dos mais assistidos do canal, já tendo alcançado mais de 28.000 visualizações $^{18}$, e seguindo disponibilizado em seu canal:

Figura 4: QRcode "\#TUTORIAL | Olho tudo + Boca tudo | Esfumado preto com glitter | Antonio Campagna"

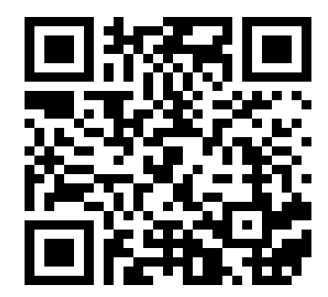

Fonte: Criado pelas autoras.

\footnotetext{
${ }^{18}$ Dados referentes a fevereiro de 2019.
} 
Figura 5: Print da página de abertura do Canal Antonio Campagna

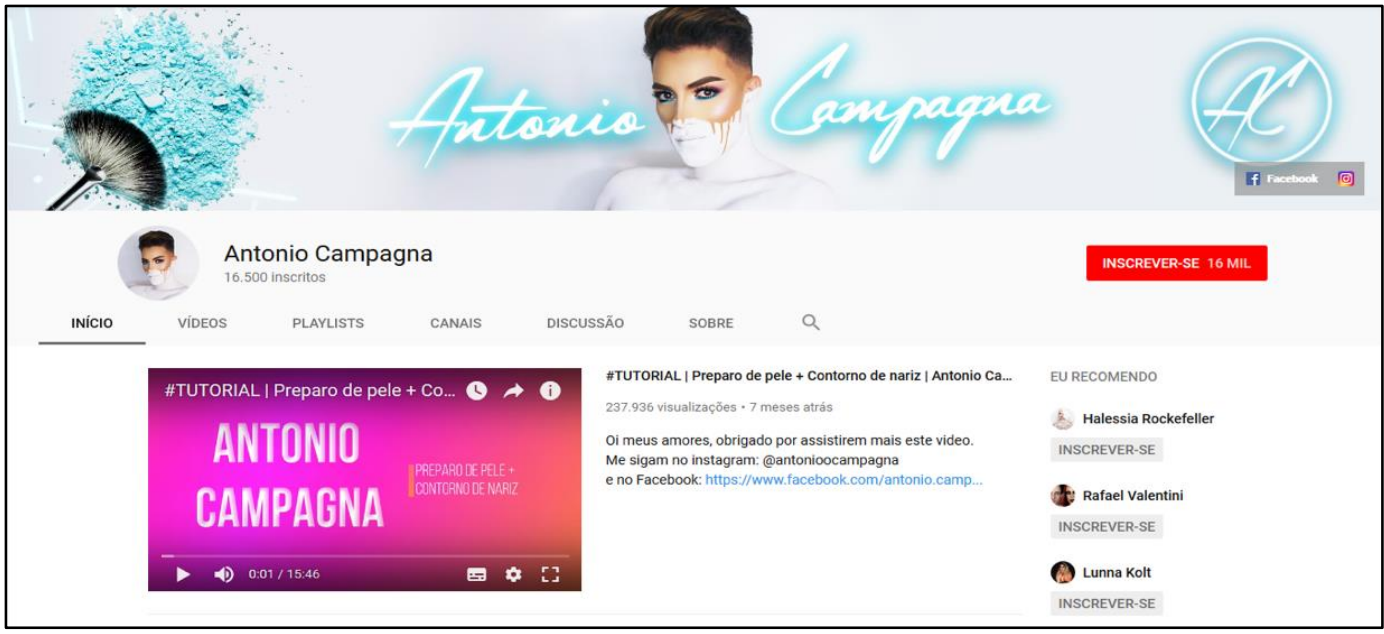

Fonte: Captura de tela - Canal do YouTube Disponível em: $<$ https://www.youtube.com/channel/UCciPFREyZjAX2-JsIyexcbw>.

A primeira e evidente constatação à análise do "\#TUTORIAL | Olho tudo + Boca tudo | Esfumado preto com glitter | Antonio Campagna" é o total conforto do youtuber e de seus viewers com o fato de ele ser um jovem que, não apenas domina as técnicas da maquiagem, mas expressa essa relação do masculino com a maquiagem com total liberdade e prazer.

O título é o primeiro elemento para o engajamento do espectador, Campagna já chama a atenção dos seus seguidores, dizendo exatamente o que irá ensinar. Como vemos no título do tutorial em questão, em que anuncia a proposta de make "boca tudo + olho tudo", isto é, uma maquiagem marcante nos olhos e nos lábios, elemento que nem sempre é a aposta principal dos maquiadores, tendo em vista que, normalmente, preferem "boca tudo + olho nada" ou vice-versa. Tal proposta reforça, previamente, uma das principais características de Campagna, a ousadia em suas maquiagens. 


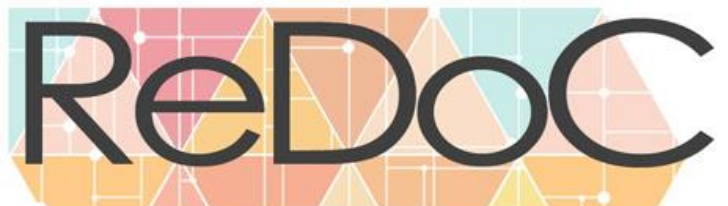

Revista Docência e Cibercultura

Figura 6: Thumbnail do \#TUTORIAL | Olho tudo + Boca tudo | Esfumado preto com glitter

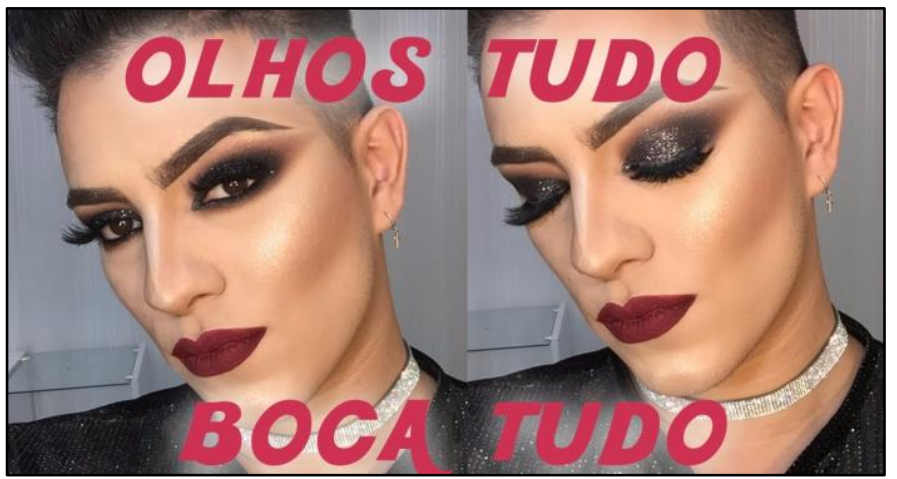

Fonte: Google Imagens.

Na descrição do vídeo, o maquiador/youtuber apresenta rapidamente o conteúdo do vídeo: “Oi genteeeee alokaaaaaa! Saiu mais um \#tutorial pra vocês, comentem aí ideias de temas para tutoriais. Os produtos makiê eu sempre compro com a @ makie_aninhagimenez, ela envia para todo Brasil. Bjos.” (COMPAGNA, 2017). Desde o início do vídeo, Campagna demonstra-se muito feliz com mais um tutorial, dirigindo-se diretamente a seus viewers: "oi genteee" e utilizando seu bordão de autoidentificação: “Alookaaaa!”.

Figura 7: Print do \#TUTORIAL | Olho tudo + Boca tudo | Esfumado preto com glitter

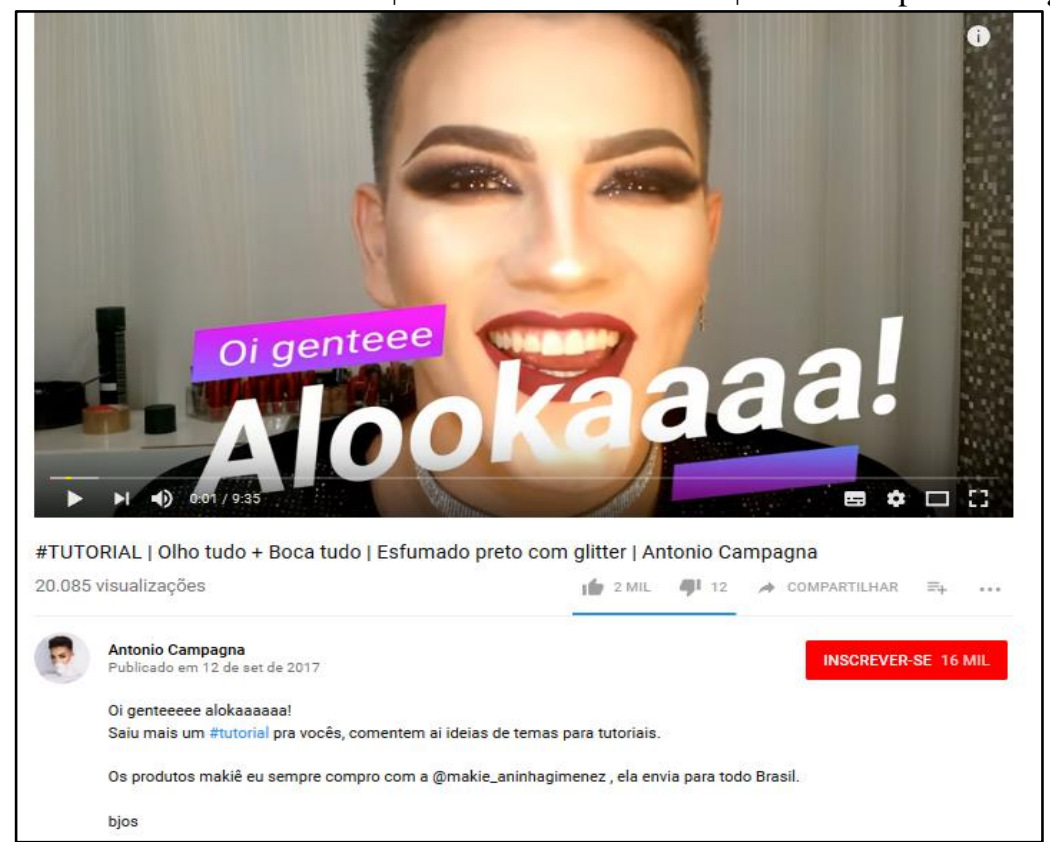

Fonte: Captura de tela - Canal do YouTube <https://www.youtube.com/watch?v=h4F1SsLmxGw> 


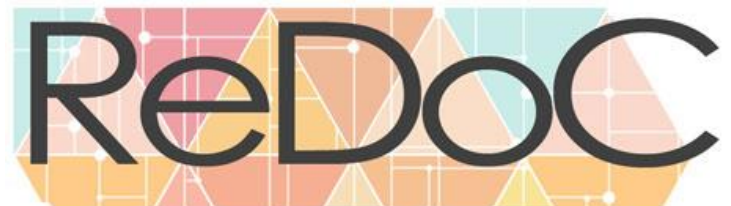

Revista Docência e Cibercultura

O youtuber é objetivo e direto em seu vídeo, tanto em relação à duração que é de 9min e $35 \mathrm{~s}$, quanto em relação ao modo como o desenvolve, como em relação à edição, deixando claro nos primeiros minutos do tutorial: "já tô com a pele pronta, tô fazendo uma técnica que chama baking $^{19}$, que você passa o pó translucido e deixa aqui, e minha sobrancelha, agora vamos fazer o olho, que é o que tá combinado para fazer nesse vídeo", (transcrito do vídeo). O tutorial é gravado em um ambiente neutro, de tons claros, com o intuito de centralizar a atenção do viewer no rosto do maquiador, que se apresenta com a blusa escura e com uma gargantilha brilhosa, atraindo a atenção para si.

Campagna sempre tenta apresentar outras opções de soluções ou produtos para ajudar seus seguidores que possam ter dificuldade em ou efetuar alguma técnica ou em encontrar algum produto. Isso revela sua íntima relação de troca com seus seguidores, reiterada sempre ao final dos tutoriais, momento em que ele instiga a interação por meio de likes ou de sugestões, colocando-se ainda à disposição para esclarecer possíveis dúvidas. Ao finalizar o vídeo o youtuber menciona outros de seus tutoriais, nos quais ensina a como "fazer" a pele - preparar e uniformizar a pele para a maquiagem com produtos de beleza; e o "contorno" - efeito de maquiagem que acentua ou atenua as linhas do rosto; e reitera que os produtos podem ser encontrados pelo Instagram - @antonioocampagna - outro meio utilizado pelo maquiador para expor seu trabalho e interagir com seus seguidores, que é indicado na legenda do vídeo.

Em relação à realização do “\#TUTORIAL | Olho tudo + Boca tudo | Esfumado preto com glitter | Antonio Campagna", o maquiador/youtuber utiliza recursos, como: a edição, a montagem e o corte; a utilização da Time Lapse $^{20}$ - que permite adiantar a ação apresentada, poupando tempo, quando, por exemplo, ele está esfumaçando a sobra; a inserção de legendas para facilitar a compreensão e chamar a atenção da técnica usada: "Esfume a sombra bem na linha do côncavo";

\footnotetext{
${ }^{19}$ Segundo o site Tudo sobre Make (2015), a técnica baking “consiste na aplicação de uma camada, generosa, de pó translúcido sobre o corretivo líquido ou cremoso na região abaixo dos olhos, e deixá-lo por uns bons 10 a 20 minutos. A intenção é obter um acabamento perfeito, sem dobrinhas, poros abertos ou acúmulos de produto em linhas finas, e funciona segundo o princípio de que o calor e os óleos da pele vão fundir os produtos de texturas opostas - creme e pó - durante esses 10 a 20 minutos, criando um efeito natural e perfeito.”

20 De acordo com o site Olhar Digital (2016), a técnica Time Lapse, conhecida como a "técnica do vídeo acelerado", é o modo como "a câmera capta apenas um fotograma a cada espaço de tempo pré-determinado; na hora de reproduzir essas imagens em sequência, o tempo parece correr muito mais rápido, criando essa sensação de velocidade".
} 


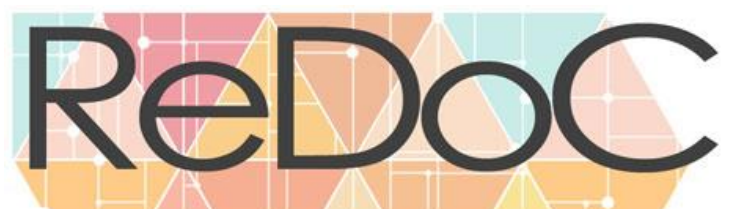

\section{Revista Docência e Cibercultura}

e bordões engraçados que são apresentados em cores vibrantes "Cuidado com a burra", "Aloka!", que colaboram ainda para o clima descontraído e íntimo do vídeo.

A linguagem utilizada por Campagna, além de ser acessível e descontraída, caracteriza-se claramente como camp, tendo em vista: a utilização de gírias e expressões reconhecidas como pertencentes à comunidade LGBTTTQIA como, por exemplo: “Alookaaaa" (aglutinação de "a louca"), uma das mais recorrentes em seus vídeos, utilizada para destacar comportamentos exagerados ou atitudes imprevisíveis; a presença da ironia e do deboche (em relação a si mesmo "aloca"; "cuidado com a burra"); a imitação teatralizada e acentuada da linguagem feminina, manifesta também na utilização de diminutivos e do gênero, e, sobretudo, a maneira afetiva como o youtuber se dirige a seus viewers, por exemplo, chamando-os de "preciosos" - elementos que constituem valores significantes em sua fala e contribuem para a conexão, por meio da identificação e da alteridade, com seus seguidores.

A beleza andrógena de Campagna acentuada pela maquiagem - ele começa o vídeo apresentando-se maquiado para mostrar a seus espectadores qual será o resultado do tutorial, para posteriormente mostrar o processo da automaquiagem; é também um importante elemento, levando-se em consideração a afirmação de Sontag, que reconhece nessa característica o mais eminente elemento dessa sensibilidade. A androgenia de Campagna pode ser entendida, então, como representatividade Queer, à medida que não há em suas automaquiagens o desejo de assumir uma representação feminina nem tampouco Drag. Aliás, Campagna lamenta que as pessoas confundam seu trabalho com sua identidade de gênero: "As pessoas comentam nas minhas fotos que foram publicadas: 'está linda, está maravilhosa', tudo no feminino. Elas confundem tudo, pois é só para mostrar meu trabalho. Sou homossexual, mas nem por isso quero ser mulher" (LOPES, 2017). O que evidencia a dificuldade de muitas pessoas em situar representações identitárias que não se enquadrem em padrões heteronormativos, sejam hetero ou homossexuais, sendo esse campo de indistinção e de questionamento de certezas, justamente, o que configura o Queer. 


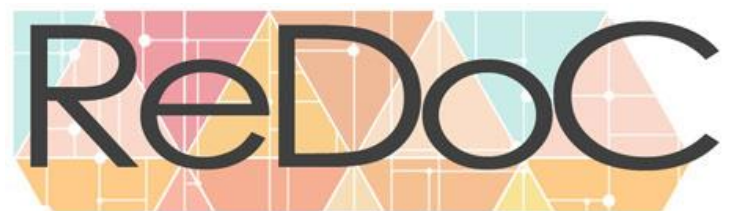

Revista Docência e Cibercultura

\title{
CONSIDERAÇÕES FINAIS
}

No momento em que Campagna se expõe fisicamente - gestual, maquiagem, vestuário, linguajar - bem como por meio das questões que aborda em seus tutoriais, mesmo que sem a intenção de levantar uma bandeira identitária, ele se configura como representatividade, pois, como afirma Butler:

\begin{abstract}
As representações possuem um papel de extrema importância no que diz respeito às questões identitárias, haja vista, que muitos dos comportamentos reproduzidos em sociedade talvez se tornem "fato" por meio de repetições midiáticas [...]. Se por um lado nunca se está pleno com a identidade. Como se pode ser o que não se pode ver? O gênero é a estilização repetida do corpo, um conjunto de atos repetidos no interior de uma estrutura reguladora altamente rígida, a qual se cristaliza no tempo para produzir a aparência de uma substância, de uma classe natural de ser. (BUTLER, 2014, p.69)
\end{abstract}

Kathryn Woodward (2014, p. 18) também chama atenção para a importância das representações, por meio das quais "damos sentido à nossa experiência e àquilo que somos. Podemos inclusive sugerir que esses sistemas simbólicos tornam possíveis àquilo que somos e aquilo no qual podemos nos tornar". Nesse sentido, o sucesso de Campagna, bem como de outros maquiadores/youtubers é algo importante para o questionamento de padrões heteronormativos de gênero, que foram sendo cristalizados por performatividades, sendo uma assim uma forma de marcar um desvio e uma ruptura quanto a questões que nos formam e que nos são ensinadas como sendo naturais. E, assim, para além do sucesso comercial em relação aos conteúdos apresentados por esses vídeos, eles se configuram, também, e talvez sem intensão ou percepção, em referenciais de identidades e subjetividade para muitos que não tinham ate então onde buscar tal identificação ou interlocução, estabelecendo-se assim uma identificação entre alguns dos viewers e os youtubers.

O sucesso dos tutoriais de Campagna pode ser associado à objetividade e à clareza para ensinar seus espectadores a se automaquiarem, utilizando uma linguagem simples e coloquial, que apresenta expressões próprias do universo da maquiagem combinadas a uma linguagem camp. Ademais da linguagem, o exagero e a androgenia revelam a sensibilidade camp que revela a essência Queer dessas narrativas. Essas marcas Queer constroem um discurso que, mesmo sem 


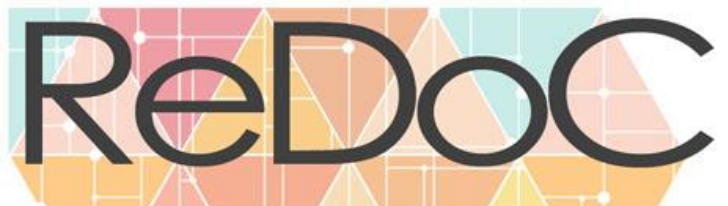

\section{Revista Docência e Cibercultura}

a intenção direta de seu autor/narrador/protagonista, desconstrói e subverte a expectativa heteronormativa que associa a maquiagem ao feminino e à mulher, desconstruindo assim estereótipos de gênero. Além disso, essas produções desmitificam essas representações, apresentando uma performance discursiva estética que retira o homem maquiado da margem social (travesti, transformista) e do estereótipo humorístico e/ou performático (Drag), e o ressignifica e o reconfigura em um cotidiano andrógeno e/ou fluido.

Essas narrativas revelam o potencial do YouTube enquanto espaço para desconstrução e questionamento de estereótipos e preconceitos, bem como enquanto espaço para afirmações indentitárias libertas, inclusive, da própria autoafirmação. E oferecem coisas diferentes a públicos diferentes, uma vez que subjacente ao interesse em aprender algum truque de automaquiagem alguns viewers estarão se aproximando da alteridade na representatividade do outro, enquanto outros podem justamente reafirmarem-se na identificação com o outro. Nesse sentido é importante termos em mente o imbricamento entre os universos - real/virtual, que coexistem em uma dinâmica de interação e tensão, vislumbrando a forma como essas questões constituídas no ambiente do "virtual" podem influenciar no mundo "real".

Nesse jogo de quebra de paradigmas de gênero estabelecido por esses tutoriais de maquiagem, o "anonimato" do viewer instaura também uma liberdade para jovens meninos se aventurarem a conhecer sem culpa ou medo o universo da maquiagem e automaquiagem. $\mathrm{Ou}$ seja, a regra de que o rosto a ser maquiado é o feminino (mesmo no campo do travestimento, da transexualidade e/ou da performance teatral) é completamente apagada. No entanto, nos comentários do tutoriais há uma preponderância de manifestação de mulheres, que encontram a maneira ideal para se automaquiarem na performance de automaquiagem do jovem e belo maquiador-youtuber Antonio Campagna. A maquiagem é mostrada como arte, uma competência liberta das amarras de gênero, cuja beleza rompe com preconceitos. Para Campagna, a “maquiagem é libertadora, é ampla, é arte” (JORNALISMO, UCDB, 2017).

Nesse sentido, falamos em representatividade Queer nos tutoriais de maquiagem de Campagna a partir da proposição de Donald Morton para quem "Ser gay é ter uma simples identidade" enquanto "ser queer é entrar e celebrar o espaço lúdico de uma indeterminação textual” (MORTON, 2002, p. 121). Essa celebração lúdica da indeterminação é evidente no tutorial de maquiagem de Campagna, à medida que seus discursos audiovisuais desestabilizam 


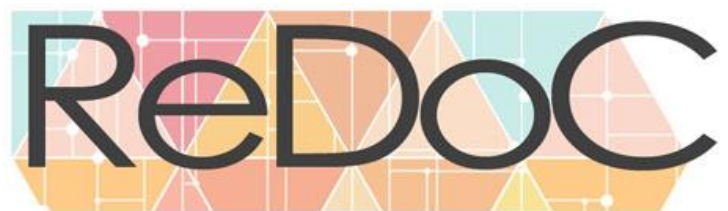

\section{Revista Docência e Cibercultura}

padrões heteronormativos e questionam antigas certezas de gênero, brincando com a possibilidade de transitar por essas posições e, sobretudo, de misturá-las. Nesse sentido, mais do que uma representação gay ou de homossexualidade esses tutoriais surgem como espaço lúdico de fruição da indeterminação que o Queer promove e celebra.

\section{REFERÊNCIAS}

\#TUTORIAL | OLHO TUDO + BOCA TUDO | ESFUMADO PRETO COM GLITTER. 9min. Disponível em: <https://www.youtube.com/watch?v=h4F1SsLmxGw> Acesso em: 10 jan. 2018.

AMORIM, Lauro Maia. Tradução \& identidade. In: AMORIM, LM.; RODRIGUES, CC.; STUPIELLO, ÉNA. (Orgs.). Tradução \& perspectivas teóricas e práticas [online]. São Paulo: Editora UNESP; São Paulo: Cultura Acadêmica, 2015, pp. 155-182. Disponível em: <http://books.scielo.org/id/6vkk8/pdf/amorim-9788568334614-08.pdf > Acesso em: 29 abr. 2018.

BUTLER, Judith. Problemas de Gênero: Feminismo e Subversão da Identidade; tradução Renato Aguiar. 2 ed. Rio de Janeiro: Civilização Brasileira, 2008.

Regulações de gênero. Cad. Pagu. São Paulo, n.42, p. 249-274. 2014,

COSTA, Bruno. Personagens de si nas videogra as do YouTube. Revista Eco-Pós, Rio de Janeiro, v.12, n.2, p. 206-219, maio-ago. 2009

COSTA, Milane do Nascimento; SILVA JÚNIOR Claudio Gomes da. "Que Bicha É Essa?" Uma Análise da Cultura Gay na Internet: Comportamentos, Subjetividades e Linguagens. 2014. Disponível em: <http://eventos.livera.com.br/trabalho/98-1020785_01_07_2015_00-4040_9276.PDF >. Acesso em: 29 abr. 2018.

ELLIS, Rowan. O YouTube é anti-LGBTQ? 2017. Disponível em: <https://www.youtube.com/watch?v=Zr6pS07mbJc> Acesso em: 29 abr. 2018.

JENKINS, Henry. O que aconteceu antes do YouTube? In: BURGESS, Jean; GREEN, Joshua. YouTube e a Revolução Digital: como o maior fenômeno da cultura participativa transformou a mídia e a sociedade. Tradução Ricardo Giassetti. São Paulo: Aleph, 2009

JORNALISMO UCDB 2017. DEU CERTO MULTIMÍDIA - ANTONIO CAMPAGNA. UCDB, 2017. 40min. Disponível em: <https://www.youtube.com/watch?v=6d65pMTXhFA\&t=672s > Acesso em: 11 jan. 2018. 


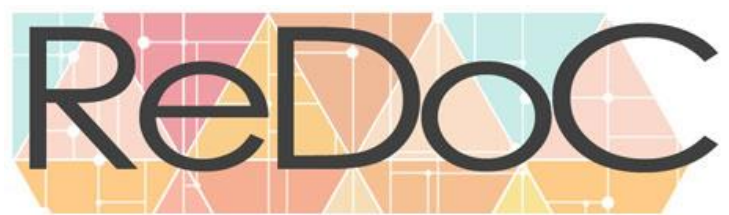

\section{Revista Docência e Cibercultura}

KOTLER, Philip. La mejor publicidad es la que hacen los clientes satisfechos, 2017. Disponível em: <https://www.unav.edu/documents/4889803/13079787/62_Orvalle++La+evoluci\%C3\%B3n+del+Marketing+tradicional+al+de+influencia+Los+influencers.pdf/5d9 ee093-ff02-1d1a-c20f-714e021e9c5d> Acesso em: 30 abr. 2018.

LOPES, Denílson. O homem que amava rapazes e outros ensaios. Rio de Janeiro: Aeroplano, 2002.

LOPES, Mariana. Com efeitos extravagantes, maquiador faz tutoriais para conquistar a internet, 2017. Disponível em: < https://www.campograndenews.com.br/lado-b/comportamento23-08-2011-08/com-efeitos-extravagantes-maquiador-faz-tutoriais-para-conquistar-a-internet> Acesso em: 29 abr. 2018.

LOURO, Guacira L. Um corpo estranho: ensaios sobre sexualidade e teoria queer. Belo Horizonte: Autêntica Editora, 2013.

MENEGON, Érika Nogueira. Imagens e Narrativas midiáticas: Análise dos Vídeos do YouTube. (Dissertação) Programa de Pós-graduação em Educação da Faculdade de Filosofia e Ciências, da Universidade Estadual Paulista - UNESP - Campus de Marília. 152f. Disponível em: $<$ https://www.marilia.unesp.br/Home/PosGraduacao/Educacao/Dissertacoes/menegon_en_m e_mar.pdf $>$ Acesso em: 12 jan. 2018.

MONTANHA, Fausto Amaro Ribeiro Picoreli. Por um estudo dos vlogs: apontamentos iniciais e contribuições teóricas de Marshall McLuhan. Contemporânea. 2011. Disponível em $<$ http://www.contemporanea.uerj.br/pdf/ed_18/contemporanea_n18_12_Fausto_Amaro_Ribei ro_Picoreli_Montanha.pdf $>$. Acesso em: 02 abr. 2018.

WESCH, Michael. No texto Youtube and youexperiences of self-awareness in the context collapse of the recording webcam. EME, 2009. Disponível em: <https://krex.k-

state.edu/dspace/bitstream/handle/2097/6302/WeschEME2009.pdf > Acesso em: 29 abr. 2018.

MORTON, Donald. El nacimiento de lo ciberqueer. In: JIMÉNEZ, Rafael M. Mérida.

Sexualidades transgresoras. Una antología de estudios queer. Barcelona: Icária editorial, 2002, p. 111-140.

SCHECHNER, Richard. Performance teoria y prácticas interculturales. Buenos Aires: Libros del Rojas - Universidade de Buenos Aires, 2000; p. 13.

SANTAELLA, Lucia. Culturas e artes do pós-humano: da cultura das mídias à cibercultura. São Paulo: Paulus, 2003.

SANTAELLA, Lucia. Linguagens líquidas na era da mobilidade. São Paulo: PAULUS, 2007. 
SCOLARI, Carlos. LIBRO BLANCO - Alfabetismo Transmedia en las nuevas Ecología de los Medios. Disponível em:

<https://repositori.upf.edu/bitstream/handle/10230/33910/Scolari_TL_whit_es.pdf > Acesso em: 27 abr. 2018.

SCHECHNER, Richard. O que é performance? In: Performance studies: an introduccion, second edition. New York \& London: Routledge, 2006.

SIBILIA, Paula. O Show do eu. A intimidade como espetáculo. Rio de Janeiro. Editora Nova Fronteira, 2008.

SONTAG, Susan. Notes On “Camp”, 1964. Disponível em:

$<$ https://faculty.georgetown.edu/irvinem/theory/Sontag-NotesOnCamp-1964.html >. Acesso em: 29 abri. 2018.

THOMPSON, John B. A nova visibilidade. MATRIZES, USP, São Paulo, v. 1, n. 2, abr. 2008, p. 15-38. Disponível em: <http://www.periodicos.usp.br/matrizes/article/view/38190/40930> Acesso em: 25 abr. 2018.

TUDO SOBRE MAKE. 'Baking', técnica de contorno que é dica para um acabamento perfeito, é a sensação de maquiagem do momento. Disponível em:

$<$ http://www.tudosobremake.com.br/noticia/-baking-tecnica-de-contorno-que-e-dica-para-umacabamento-perfeito-e-a-sensacao-de-maquiagem-do-momento_a5618/1> Acesso em: 10 jan. 2018.

WOODWARD, Kathryn. Identidade e diferença: uma introdução teórica e conceitual. In: SILVA, T. T. da (Org). Identidade e diferença: a perspectiva dos Estudos Culturais. 1 ed. Petrópolis, RJ: Vozes, 1999. (p.7-72). 